\title{
Characterization and Antitumor Activity of
}

\section{Chitosan/Poly (Vinyl Alcohol) Blend Doped with Gold and Silver Nanoparticles in Treatment of Prostatic} Cancer Model

\author{
A. Abaza ${ }^{1}$, E. A. Hegazy ${ }^{2}$, Ghada. A. Mahmoud ${ }^{2}$ and B. Elsheikh ${ }^{3}$ \\ 1. Nuclear and Radiological Regulatory Authority (ENRRA), Cairo11762, Egypt \\ 2. National Center for Radiation Research and Technology (NCRRT), Atomic Energy Authority, Cairo 11787, Egypt \\ 3. Faculty of Science, Al-Azhar University, Nasr City, Cairo 11371, Egypt
}

\begin{abstract}
The application of nanotechnology in various fields of science has earned a great concern over the past decades. The natural products and surface-modified polymers and metallic nanoparticles (NPs) have evolved as promising nanomaterials for targeted prostate cancer treatment. In the present study, Chitosan/poly (vinyl alcohol) (Cs/PVA) blend was synthesized by gamma radiation which could behave a nanoreactor for silver $(\mathrm{Ag})$ and gold $(\mathrm{Au})$ nanoparticle with promising anticancer applications. $(\mathrm{Cs} / \mathrm{PVA} / \mathrm{Ag})$ and (Cs/PVA/Au) nanocomposites were confirmed by SEM (scanning electron microscope) and TEM (transmission electron microscope) analysis. The swelling properties have been investigated as a function of time and $\mathrm{pH}$. The anti-cancer activity of the prepared nanocomposites was demonstrated in prostatic cancer cell line. It has a significant effect against prostatic cancer. However, metal nanoparticles have shown a good experimental success in the field of nanomedicine especially in cancer treatment, which has always been an area of high concern. The collaboration of biomedical research in the identification and characterization of biomedical strategies using the interesting metal nanocomposite will impact the future nanomedicine greatly.
\end{abstract}

Key words: Chitosan, nanocomposite, silver nanoparticles, gold nanoparticles, prostatic model.

\section{Introduction}

Chitosan is a cationic polysaccharide. It is a copolymer of $\mathrm{N}$-acetyl glucosamine and glucosamine unit obtained mainly from $N$-deacetylation of chitin. It has been extensively employed in biological and biomedical applications owing to its biocompatibility and biodegradability [1]. It can swell in water due to extensive crosslinking, retaining a significant fraction of water within their structure of several functional groups (i.e., amino, carboxyl, amide, hydroxyl and sulphonic) in the polymers of the hydrogel forming

Corresponding author: Aya Abaza, Ph.D., M.D. assistant professor doctor of safety and prevention of oncology, research field: characterization and cytotoxicity of chitosan/poly (vinyl alcohol) blend doped with gold and silver nanoparticles in treatment of prostatic cancer cell line. network without dissolving [2]. Additionally, chitosan is versatile biopolymer that is inexpensive and contains some important physiological properties such as biodegradable, biocompatible, non-toxic, non-allergenic and mucoadhesive properties for mammals. These properties of chitosan make it suitable to be used in various fields including biomedicine, agriculture, cosmetics, environmental protection, food, fiber industries and wastewater management [3]. It has an antimicrobial activity and can change into any shape and size, such as films, microspheres, nanoparticles, porous membranes and scaffolds. They have been studied for various applications in different fields: medicine, pharmacy, biotechnology and controlled drug release [2]. In medical fields chitosan has been used as wound healing, tissue engineering, 
and drug delivery $[1,4,5]$.

Nanotechnology has induced a paradigm shift in biomedical sciences, especially in the field of cancer therapy and diagnostics due to advancement of nanoparticles, nanotubes and nanowires over the normal materials. There have been advances in the development of efficient nanodrug delivery systems with reduced side effects compared with the use of conventional drugs for cancer treatment. The nanoparticles of noble metals with advancement of new materials have been successfully developed for different purposes in engineering and biological sciences [6, 7]. Gold nanoparticles (Au-NPs) are likely to provide an attractive platform for combining a variety of bio-physiochemical properties into a unified nanodevice with great therapeutic potential [8]. The inertness and biocompatibility of Au-NPs make them very promising for specific applications such as medical imaging, drug delivery, gene delivery, and molecular sensing [9]. On the other hand, silver nanoparticles (Ag-NPs) have been intensively studied because of their effective use in drug delivery [10], biomedical [11-13], textile industries [14], water treatment [15], food industries [16], agriculture [17], catalysis and SERS (surface-enhanced Raman scattering) [7].

Generally, metal NPs agglomerate due to high active surface area. To stabilize and control the NPs structures, various surfactants, polymers, dendrimers, biological templates, and biomacromolecules were used [18]. By considering the importance of hydrogel networks and natural polymers (carbohydrates) such as dextran, starch, carboxymethylcellulose, acacia as effective carriers for nano-systems, prompted us to draw a new idea in which semi-inter penetrating network (IPN) hydrogels prepared in presence of prepolymers that would be better choice to cook metal nanoparticle in their networks [19]. Hydrogels offer large free space between the cross-linked networks in the swollen stage that can act as a nanoreactor for the nucleation and growth of the NPs [20]. For this purpose, the combination of poly ( $N$-vinylpyrrolidone) (NVP) hydrogel and dextran systems is selected because of their more relevance for pharmaceutical and biomedical applications [21].

In this study (Cs/PVA) hydrogel and (Cs/PVA/Ag) and (Cs/PVA/Au) nanocomposite were prepared by gamma irradiation. They were confirmed by Scanning SEM (scanning electron microscope) and TEM (transmission electron microscope) analysis. The swelling properties have been investigated as a function of time and $\mathrm{pH}$. The anti-cancer activity of the prepared nanocomposites was demonstrated in human prostate cancer cell line PC3.

\section{Materials and Methods}

\subsection{Materials}

A medium molecular weight chitosan (Cs) and Poly (vinyl alcohol) (PVA) of MW 15,000 kg/mol were supplied from Sigma-Aldrich Inc and were used as received. AgNO3 purchased from oxford laboratory Mumbai (India). NaBH4 (96\%, Merck) were used without further purification. HAuCl4·3H2O purchased from Sigma-Aldrich Inc. Other chemicals were purchased from El-Nasr Co. for Chemical Industries, Egypt and used without further purification.

\subsection{Methods}

\subsubsection{Synthesis of Cs/PVA Blend}

An aqueous solution of $(10 \% \mathrm{w} / \mathrm{v})$ PVA was prepared by dissolving the determined quantity of PVA at $80^{\circ} \mathrm{C}$ in water bath with constant stirring for $6 \mathrm{~h}$. The Cs solution $(1 \% \mathrm{w} / \mathrm{v})$ was dissolved in dilute acetic acid solution $(1 \% \mathrm{w} / \mathrm{v})$ at $60{ }^{\circ} \mathrm{C}$ in water bath with constant stirring for $4 \mathrm{~h}$. Cs/PVA blends were done by mixing different ratios Cs: PVA (1:9, 1:4, and 2:3). The resulting solutions were poured into test tubes (inner diameter $5 \mathrm{~mm}$ ) and subjected to gamma-irradiation subjected to 60 Co-gamma rays at irradiation dose 30 $\mathrm{kGy}$ and dose rate $2 \mathrm{kGy} / \mathrm{h}$. The formed cross-linked blend was cut into nearly equal disks and were extracted in distilled water at $60{ }^{\circ} \mathrm{C}$ over night to 

with Gold and Silver Nanoparticles in Treatment of Prostatic Cancer Model

remove the non-cross-linked polymer, and then dried in air to constant weight.

\subsubsection{Preparation of Cs/ PVA Nanocomposites}

A $100 \mathrm{mg}$ of dried Cs/PVA blend was placed in 50 $\mathrm{mL}$ of $\mathrm{Ag}$ or $\mathrm{Au}$ ions solution of concentration 250 $\mathrm{mg} / \mathrm{L}$ for $24 \mathrm{~h}$ to dope metal ions in the blend matrix. Blends loaded metal ions were placed into distilled water for $24 \mathrm{~h}$ to remove unbound metal ions. Then, they were reduced by transferring them into $50 \mathrm{~mL}$ of $5 \%$ $\mathrm{NaOH}$ for $6 \mathrm{~h}$ and then in $50 \mathrm{~mL}$ of $0.5 \mathrm{M} \mathrm{NaBH} 4$ for another $6 \mathrm{~h}$ to complete reduction of the metal ions. Soaking them in de-ionized water for $12 \mathrm{~h}$ and drying in oven at $40^{\circ} \mathrm{C}$.

\subsubsection{Swelling Measurements}

The clean, dried and pre-weighted blend discs were soaked in distilled water or buffer solutions at $25^{\circ} \mathrm{C}$ for different interval time durations. The discs were removed and the excess water on the surface was removed by blotting quickly with filter paper and weighed. The swelling percent was calculated as follows:

$$
\text { Swelling percent }=\text { X } 100
$$

where, Ws and $\mathrm{Wd}$ are the weights of the swollen and the dried hydrogel, respectively.

\subsubsection{Instrumentations}

The morphological observation was done by Jeol JSM-5400 scanning electron microscopy SEM. TEM measurements were performed using a TEM JEOL: JEM-100cx. The composite powder was dispersed in ethanol using an ultrasonic device, placed on carbon-coated copper grids, and dried under ambient conditions for the morphological observation.

\subsection{Human Tumor Cell Lines}

Human tumor carcinoma prostate PC3 cell lines used in this study were obtained from the ATCC (American type culture collection, Minnesota, USA). The tumor cell lines were maintained at the National Cancer Institute, Cairo, Egypt, by serial sub-culturing. Samples were prepared by dissolving 1:1 stock solution and stored at $-20{ }^{\circ} \mathrm{C}$ in dimethylsulfoxide
(DMSO) at $100 \mathrm{~mm}$. Different concentrations of the drug were used $5,12.5,25,50 \mu \mathrm{g} / \mathrm{mL}$.

\subsubsection{Cell Culture and Maintenance}

RPMI-1640 medium was used for culturing and maintenance of the human tumor cell lines. It was supplied in a powder form. The working solution was prepared by dissolving $10.4 \mathrm{gm}$ powder and $2 \mathrm{gm}$ sodium bicarbonate dissolved in $1 \mathrm{~L}$ distilled water. The prepared medium was then sterilized by filtration in a Millipore bacterial filter $(0.22 \mu \mathrm{m})$ and kept in a refrigerator at $\left(4{ }^{\circ} \mathrm{C}\right)$. Before use the medium was warmed at $37{ }^{\circ} \mathrm{C}$ in a water bath and supplemented with $1 \%$ penicillin/streptomycin and $10 \%$ fetal bovine serum. A cryotube containing frozen cells was taken out of the liquid nitrogen container and then thawed in a water bath at $37^{\circ} \mathrm{C}$. The cryotube was opened under strict aseptic conditions and its contents were supplied by $5 \mathrm{~mL}$ supplemented medium drop by drop in a 50 $\mathrm{mL}$ sterile falcon tubes. The tube was incubated for $2 \mathrm{~h}$ then centrifuged at 1,200 rpm for 10 minutes and the supernatant was discarded, the cell pellet was suspended and seeded in $5 \mathrm{~mL}$ supplemented medium in T25 nunclon sterile tissue culture flasks. The cell suspension was incubated and followed up daily and the supplemented medium was replaced every 2-3 days. Incubation was continued until a confluent growth was achieved and the cells were freshly subcultured before each experiment to be in the exponential phase of growth.

2.3.2 In Vitro Cytotoxic Assay for PC3 Cancer Cell

The cytotoxicity was carried out using SRB (sulphorhodamine-B) assay following the method reported by Vichai and Kirtikara [22] and expressed as the survival fraction. SRB is a bright pink amino-anthracene dye with two sulphonic groups. It is a protein stain that binds to the amino groups of intracellular proteins under mildly acidic conditions to provide a sensitive index of cellular protein content. Cells were seeded in 96-well microtiter plates at initial concentration of $3 \times 103$ cell/well in a $150 \mu \mathrm{L}$ fresh medium and left for 24 hours to attach to the plates. 

with Gold and Silver Nanoparticles in Treatment of Prostatic Cancer Model

Different concentrations $0,5,12.5,25,50 \mu \mathrm{g} / \mathrm{mL}$ of drug (Cs/PVA, Cs/PVA/Ag, and $\mathrm{Cs} / \mathrm{PVA} / \mathrm{Au}$ ) were added. For each drug concentration, 3 wells were used. The plates were incubated for $48 \mathrm{~h}$. The cells were fixed with $50 \mu \mathrm{L}$ cold trichloroacetic acid $10 \%$ final concentration for $1 \mathrm{~h}$ at $4{ }^{\circ} \mathrm{C}$. The plates were washed with distilled water using (automatic washer Tecan, Germany) and stained with $50 \mu \mathrm{L} 0.4 \%$ SRB dissolved in $1 \%$ acetic acid for 30 minutes at room temperature. The plates were washed with $1 \%$ acetic acid and air-dried. The dye was solubilized with $100 \mu \mathrm{L} /$ well of 1.0 $\mathrm{M}$ tris base ( $\mathrm{pH} 10.5)$ and O.D. (optical density) of each well was measured spectrophotometrically at 570 $\mathrm{nm}$ with an ELISA microplate reader (Sunrise Tecan reader, Germany). The mean background absorbance was automatically subtracted and means values of each drug concentration was calculated. The experiment was repeated 3 times. The percentage of cell survival was calculated as follows: Surviving fraction $=$ O.D. (treated cells)/O.D. (control cells).

The $\mathrm{IC}_{50}$ values (the half maximal inhibitory concentration value) which are a measure of the concentrations of drug required to produce $50 \%$ inhibition of cell growth were also calculated.

\section{Result and Discussion}

\subsection{Swelling Measurements}

Swelling behavior is the most significant characteristic of hydrogels and it reflects the affinity of the chemical structure of hydrogels for water and other surrounding fluids [23]. Fig. 1 presents the water uptake of different formulations of Cs/ PVA blend as a function of time. It was observed that a rapid rate of water uptake was observed which increased with time until equilibrium over a period of $600 \mathrm{~min}(10 \mathrm{~h})$. Cs/PVA blend exhibited high water uptake due to the association/dissociation of the hydrogen bonding between the hydroxyl groups in the PVA and the amino groups in the Cs in the network [24]. It can be also noted that Cs/PVA blend of formulation $2 / 3$ has the highest water uptake $(\approx 900 \%)$. These results indicated a strong influence of the cross-linking on the water uptake. The higher cross-linked hydrogels tend to show lower water uptake because the highly cross-linked structure could not sustain much water with in the network structure [25]. In other meaning, the water uptake is higher when the network is connected with relatively low number of intermolecular bonds. Cs

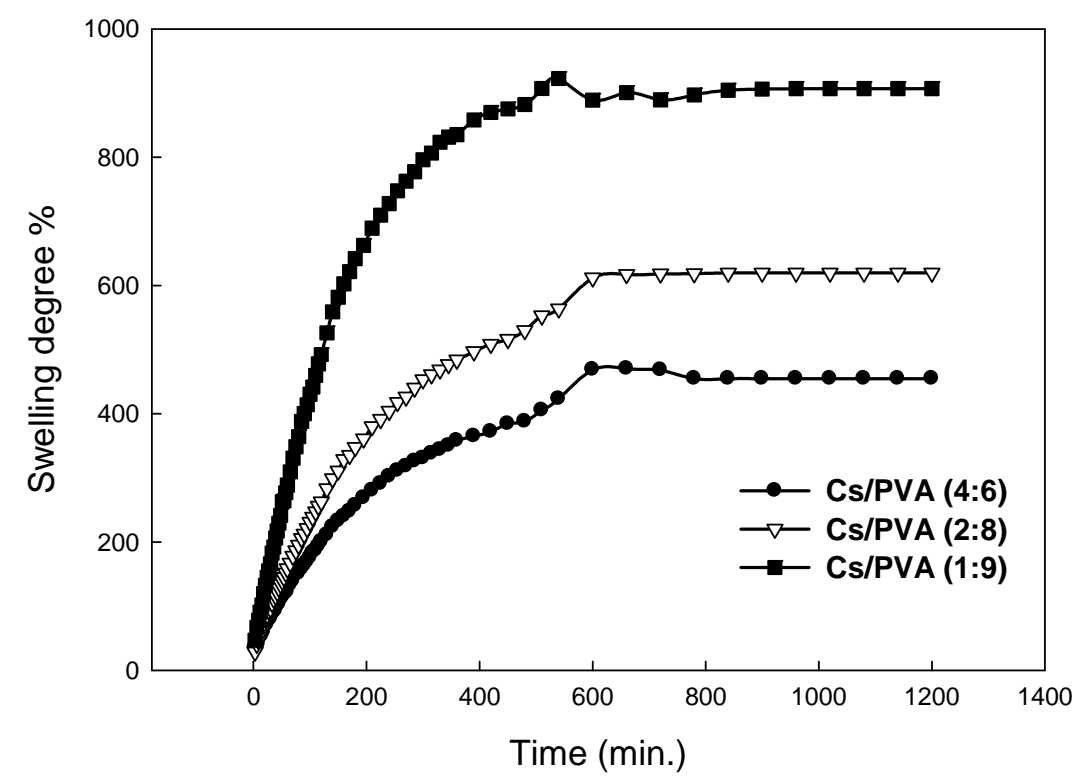

Fig. 1 Effect of time (min.) on the swelling degree of (Cs/PVA) hydrogel at irradiation doses $40 \mathrm{kGy}$. 
produced a lower cross-linked density than PVA in the Cs/PVA blend hydrogel. The presence of higher Cs content in the polymer solution diminishes the probability of radical's recombination, subsequently the cross-linking density of the gel becomes lower. Therefore, more free volumes are available in the bulk polymer consequently more water can be absorbed. So, the higher the chitosan content in the hydrogel, the lower the cross-linking density whatever, the higher water uptake obtained [26].

Fig. 2 presents the swelling percent of different formulations of $\mathrm{Cs} / \mathrm{PVA}$ blend as a function of $\mathrm{pH}$. It was observed that PVA blends containing chitosan exhibited the highest swelling capacity at $\mathrm{pH} 2$, and when $\mathrm{pH}$ is above 7 the degree of swelling changes little. Blends of high chitosan content showed a higher $\mathrm{pH}$ dependence and swelling capacity while more PVA blend does not show $\mathrm{pH}$ sensitivity and has the smallest swelling capacity. The larger swelling capacity can be due to the lower cross-linking density, while the larger $\mathrm{pH}$ sensitivity is due to the presence of more amino-groups in the blends. It is well known that the amino-groups of chitosan can be protonated in acidic media. This protonation induces electrostatic repulsions between the polymer segments. Besides, the protonation of the amino-groups may lead to the dissociation of hydrogen bonds among the polymers and thus to a relaxation of the macromolecular chains [27]. When Cs/PVA blend is in neutral or alkaline media, the swelling is strongly reduced due to the deprotonation of the amino-groups. The $\mathrm{pH}$ dependence of the extracted Cs/PVA blend is a strong indication that chitosan was successfully introduced into the formed cross-linked blended hydrogel during irradiation. The swelling behavior of Cs/PVA blend reduced to $44.7 \%$ at $\mathrm{pH} 7$ because of crosslinking [23].

\subsection{SEM}

SEM micrographs of the internal hydrogel structure show a porous filamentous matrix which could allow the transport of additives through the matrix. For of Cs/PVA blends (Fig. 3) the structure becomes less ordered and more porous with increasing Cs content. On the basis of the obtained results Cs seems to perturb the formation of PVA crystallites leading to a material with a less regular structure. It can be concluded that $\mathrm{Cs}$

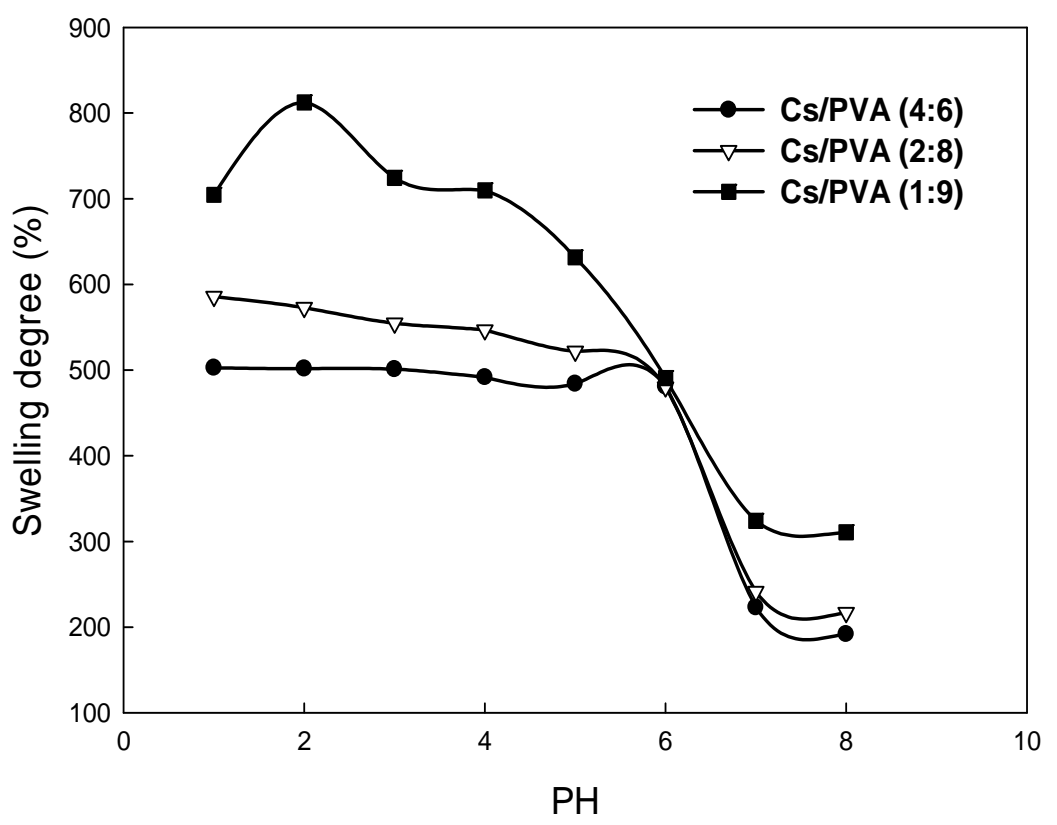

Fig. 2 Effect of pH on swelling percent of (Cs/PVA) blend at irradiation doses $40 \mathrm{kGy}$. 

with Gold and Silver Nanoparticles in Treatment of Prostatic Cancer Model

macromolecule is able to affect the material structure, chitosan a perturbing effect on PVA crystallization [28]. Fig. 3 shows the surface morphological structure of ( $\mathrm{Cs} / \mathrm{PVa})$ blend with different compositions. It can be observed that, the concentration of Cs affects the hydrogel pore structure. As seen in figure the (Cs/PVA) blend of composition (4:6) (Fig. 3C) shows larger pore structure compared with the other two compositions (1:9) and (2:8), which should be affected the degree of swelling [29]. The higher the Cs, the greater the porous size of the belnd. Our results suggested that the entangling between PVA was reduced by Cs [30]. However, the drug incorporated in the hydrogel did not significantly influence on the porosity [25]. Also, it can be observed that the network structure of the blend of composition (4:6) (Fig. 3B) has extensive surface area with a lot of cavities, which suggested a better access to ions rebinding in the blend cavities. For (Cs/PVA/AgNp) (Figs. 3D and 3F), Cs could also decrease the network densities because it induced
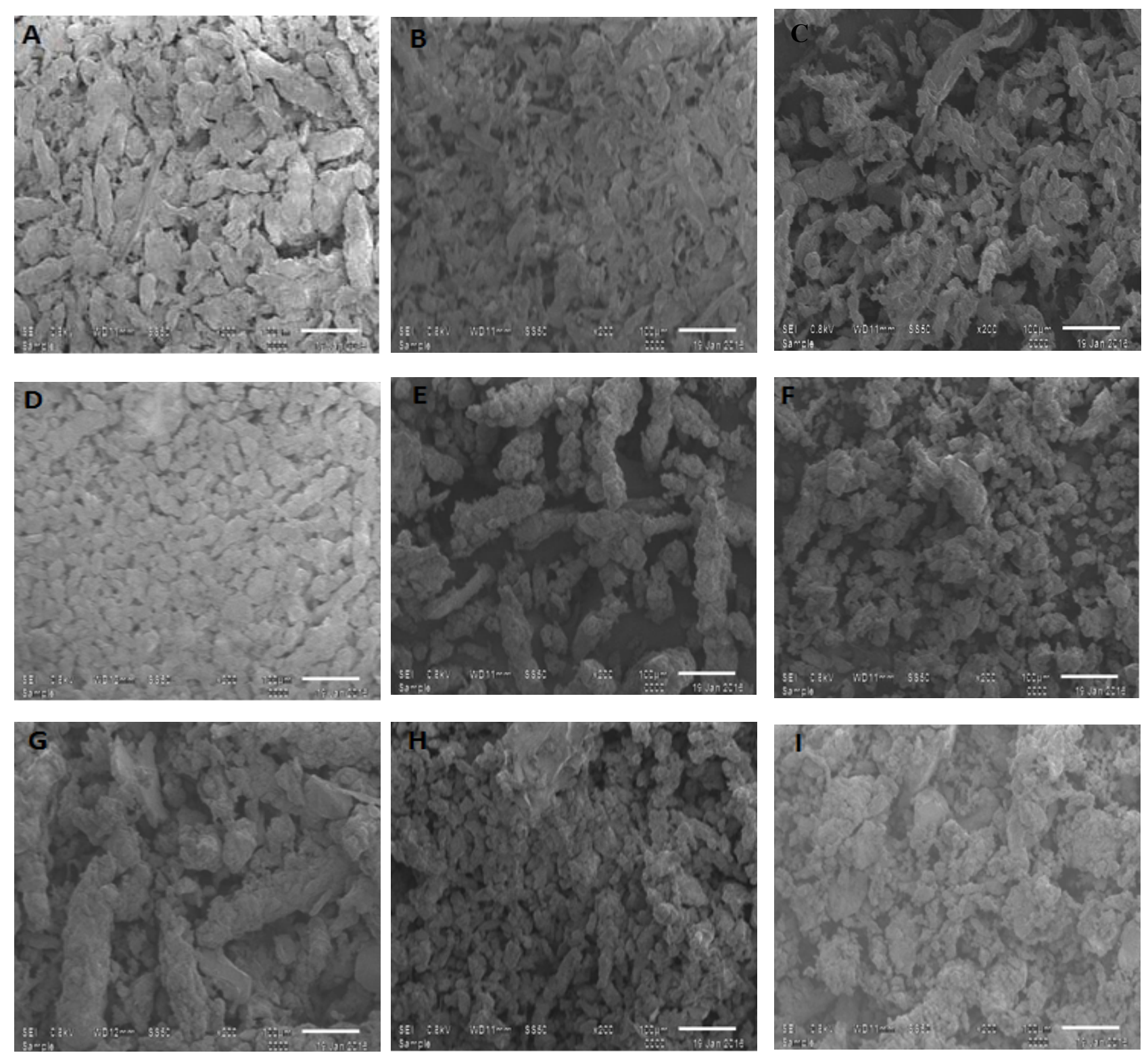

Fig. 3 SEM Cs/PVA hydrogels A) 1:9; B) 2:8; C) 4:6; D) Ag-doped 1:9; E) Ag-doped 2:8; F) Ag-doped 4:6; G) Au-doped 1:9; H) Au-doped 2:8; I) Au-doped 4:6. 

with Gold and Silver Nanoparticles in Treatment of Prostatic Cancer Model

relatively entangled porous sizes and perturbed the stable three-dimensional polymer network [31]. The higher the Cs the greater amount silver nanoparticle trapped the blend. The Cs/PVA blend has exhibited a dense and uniform plain microstructure. Whereas Cs/PVA/AgNP showed the presence of defined nanoparticles in the structure (arrows) [32]. The micrographs all Cs/PVA/AuNP (Figs. 3G and 3I) Au nanoparticles are spherical and in homogeneously shaped [33]. The higher the Cs content the smaller amount Au nanoparticles trapped the blend.

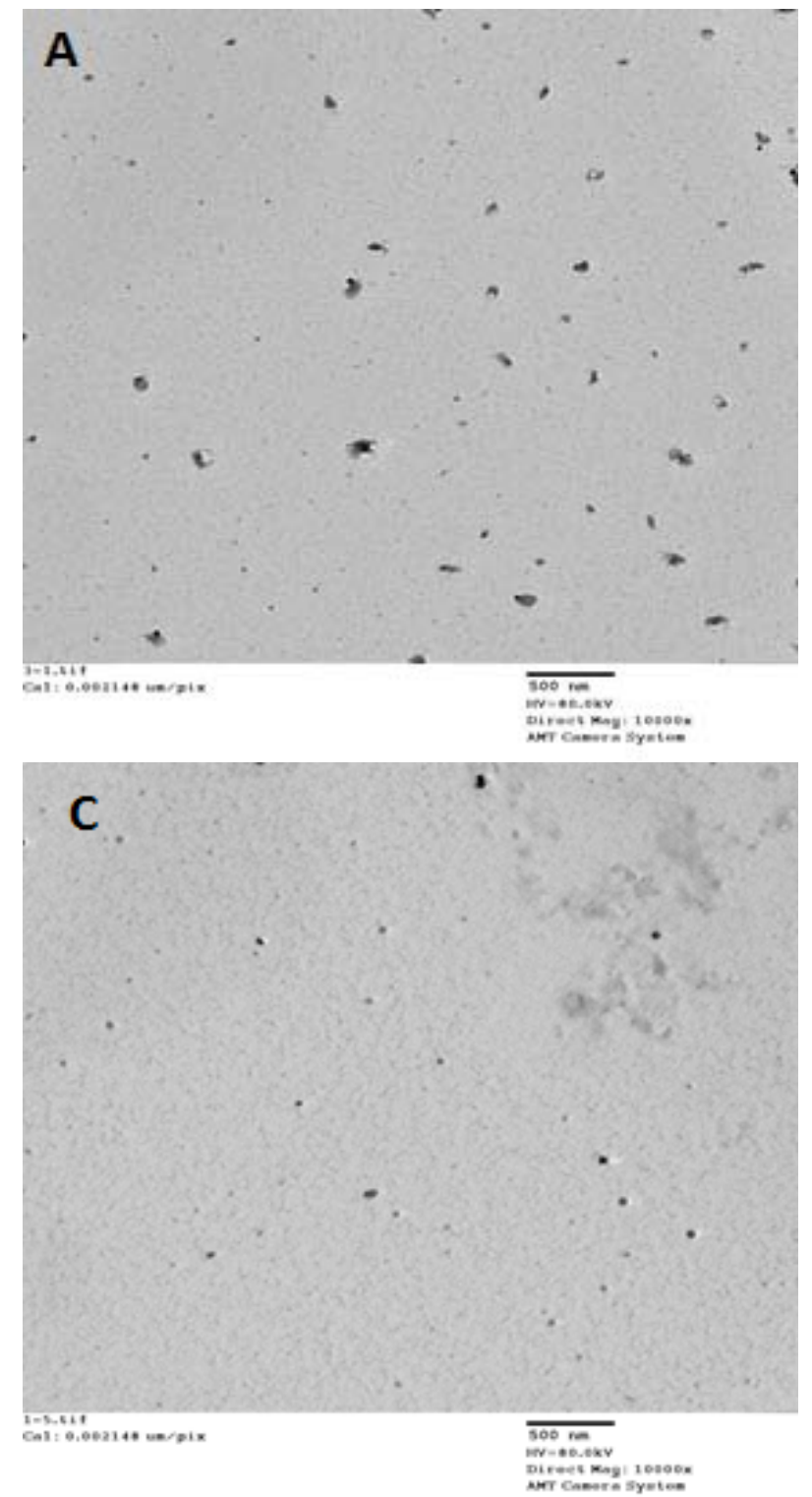

\subsection{TEM}

Nanometer-sized particles are commonly present in many different types of materials and the use of TEM allows gathering information about particle size, and shape. The TEM images of (Cs/PVA/AgNp) and (Cs/PVA/AuNp) nanocomposites are shown in Fig. 4. The images indicated that the particles are spherical in nature with dispersed morphology. The TEM results further illustrates that the particles formed have an average size of $50 \mathrm{~nm}$ [32]. TEM study provides
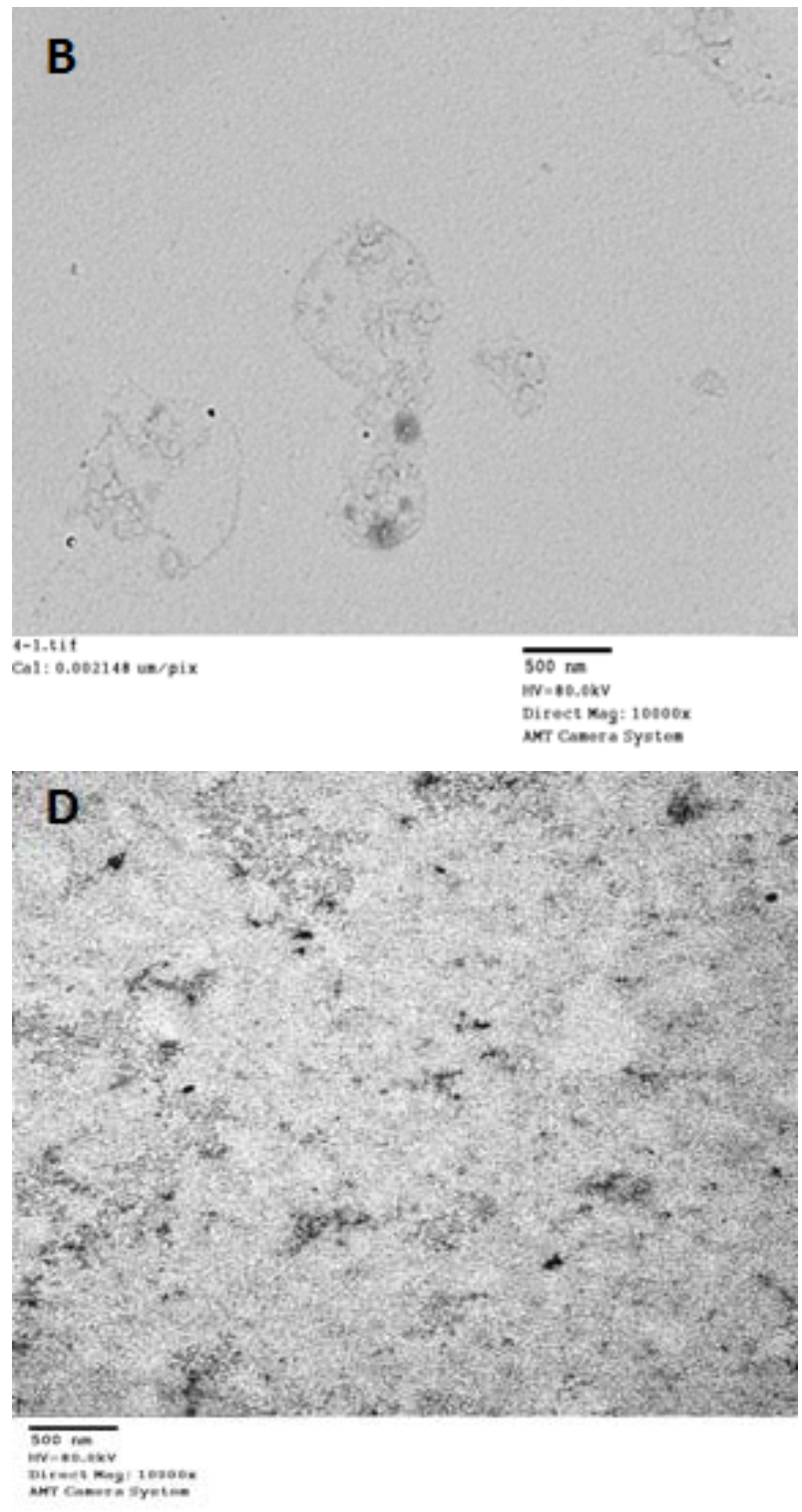

Fig. 4 TEM of A) Cs/PVA/AgNp, 10:90 wt\%; B) Cs/PVA/AgNp, 40:60 wt\%; C) Cs/PVA/AuNp, 10:90 wt\%; D) Cs/PVA/AuNp 40:60 wt\%. 
valuable information regarding size and distribution of AuNp within nanocomposites also in Fig. 5 indicated that the particles were uniform in shape and the average size of AuNp spherical particles was $36.3 \pm 50.8 \mathrm{~nm}$ [34].

\subsection{Cytotoxic Assay PC3 Cells}

Hydrogels prepared using natural chitosan have gained importance due to their promissory properties of biodegradability and biocompatibility [35]. Cs nanoparticle Cs-NP as delivered drugs accumulate selectively in tumor, rather than normal, tissues because of an enhanced permeation and retention effect [36]. In addition to its physicochemical properties, surface modifications of Cs play a crucial role in the cytotoxic profile and targeting of cancers that are characterized by rapid division and aggressive growth [37]. On the other hand, prostatic cancer has been diagnosed as the second most frequent and the sixth among the cancer-causing deaths among men worldwide [38]. Recent advancements in cancer nanotechnology have facilitated a better way to diagnosis and provide therapy for prostate cancer. Nanotechnology has the potential to battle tumors at the site, where the cancer begins [39].

Therefore, in the present study the toxic effect of the prepared Cs/PVA hydrogels were evaluated against human prostatic cancer cells to explore their possible application as a drug carrier system for anti-cancerous drugs. The $\mathrm{IC}_{50}$ values (the half maximal inhibitory concentration value) and the survival fraction on human prostate cancer cell line were calculated. The survival fraction was found to be higher in (5:5) hydrogel concentration followed by the concentration of (1:9) and (4:6). The difference was highly statistically significant ( $p$-value $\leq 0.001$ ). This indicating that, the increasing amount of Cs improves $\mathrm{IC}_{50}$ value and the survival fraction (the $\mathrm{IC}_{50}$ value was $11.3,21$, and $17.3 \mu \mathrm{g} / \mathrm{ml}$ respectively) (Table 1 and Fig. 5). However, Cs oligomers possess antitumor activity tested both in vitro and in vivo [40]. Chitosan based hydrogels have been used for breast cancer, brain tumor, localized solid tumors, primary and secondary osteosarcoma, osteolysis and lung metastasis [41-44].

Additionally, gold nanoparticles (AuNPs) have attracted much attention in the field of biomedical imaging and clinical diagnostics, in the last decade [45, 46]. These NPs can also be surface modified by attaching targeting ligands and tagged with imaging molecules for specificity and effectiveness of the cancer diagnosis and therapeutics [39]. These NPs showed very high affinity and cellular internalization toward prostate cancer cells $[47,39]$. The anti-androgen gold NPs are a novel approach to overcome the treatment-resistant and hormone-insensitive prostate cancer cells [48]. It has been observed to selectively accumulated in the prostate cancer cells that have a resistance to chemotherapy and are hormone insensitive [49]. The cytotoxic effect of various concentrations of Cs/PVA/AuNP (5, 12.5, 25 and $50 \mu \mathrm{g} / \mathrm{mL})$ was assessed in PC3 cell cultures using SRB colorimetric assay at $48 \mathrm{~h}$ time intervals as shown in Table 2 and Fig. 6. The survival fraction was $24.8 \%$ and $23.8 \%$ in

Table 1 Surviving fraction at $(100 \mathrm{ug} / \mathrm{mL})$ and $\mathrm{IC}_{50}$ values of different concentrations in Cs/PVA hydrogel, on prostatic cancer cell line (PC3) using SRB colorimetric assay at 48 h time intervals.

\begin{tabular}{llllllll}
\hline $\begin{array}{l}\text { Concentration } \\
(\mu \mathrm{g} / \mathrm{mL})\end{array}$ & \multicolumn{2}{c}{ Cs/PVA (1:9) } & \multicolumn{2}{c}{ Cs/PVA (4:6) } & \multicolumn{2}{c}{ Cs/PVA (5:5) } \\
\cline { 2 - 7 } & $\begin{array}{l}\text { Survival } \\
\text { fraction }\end{array}$ & $\begin{array}{l}\text { Inhibition } \\
\text { ratio } \%\end{array}$ & $\begin{array}{l}\text { Survival } \\
\text { fraction }\end{array}$ & $\begin{array}{l}\text { Inhibition } \\
\text { ratio } \%\end{array}$ & $\begin{array}{l}\text { Survival } \\
\text { fraction }\end{array}$ & $\begin{array}{l}\text { Inhibition } \\
\text { ratio } \%\end{array}$ & $p$-value \\
\hline 0.0 & 100 & 0 & 100 & 0 & 100 & 0 & \\
5.00 & 84.4 & 15.6 & 67.1 & 32.9 & 61.9 & 38.1 \\
12.5 & 70 & 30 & 61.9 & 38.1 & 47.6 & 52.4 & $<0.001$ \\
25.00 & 41 & 59 & 30.5 & 69.5 & 26.2 & 73.8 & 82.4 \\
50.00 & 25.5 & 74.5 & 27.6 & 72.4 & 17.6 & 11.3 \\
\hline $\mathrm{IC}_{50}(\mu \mathrm{g} / \mathrm{mL})$ & 21 & \multicolumn{7}{c}{17.3} & & \\
\hline
\end{tabular}




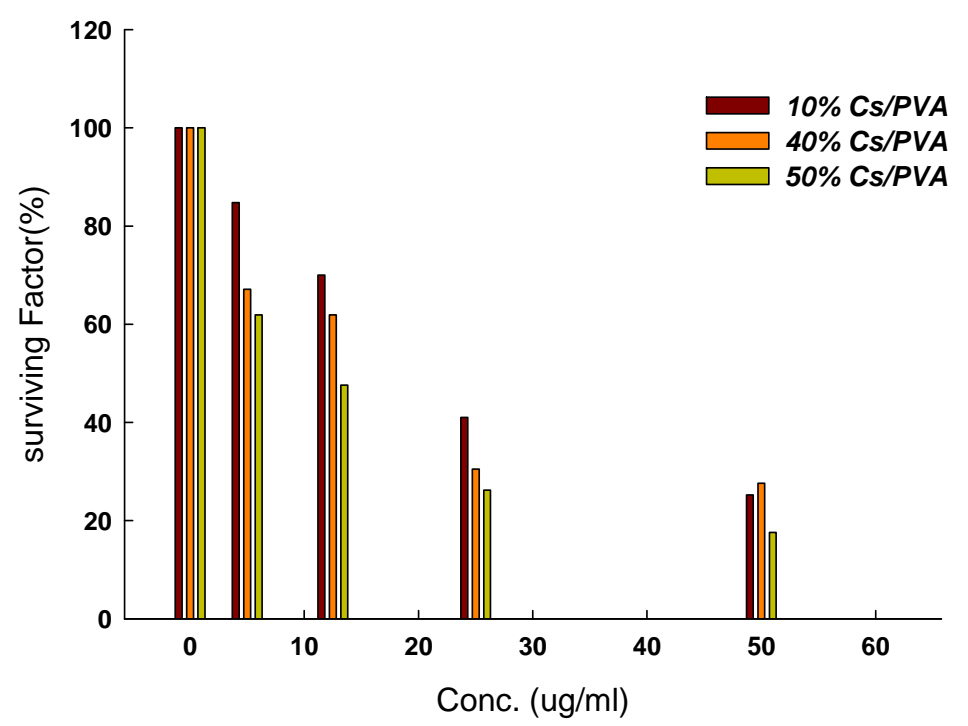

Fig. 5 Surviving factor (\%) of PC3 cells after $48 \mathrm{~h}$ treatment with different concentrations of Cs/PVA hydrogel, as calculated from the SRB assay.

Table 2 Surviving fraction \% of prostate cancer cell line (PC3) with different concentrations of Cs/PVA/AuNP at concentrations range from 5 to $50 \mu \mathrm{g} / \mathrm{mL}$.

\begin{tabular}{|c|c|c|c|c|c|c|c|}
\hline \multirow{2}{*}{$\begin{array}{l}\text { Concentration } \\
(\mu \mathrm{g} / \mathrm{mL})\end{array}$} & \multicolumn{2}{|c|}{$\begin{array}{c}\text { Cs/PVA/AuNP, Cs:PVA (1:9) } \\
(250 \mathrm{ppm}) \\
\end{array}$} & \multicolumn{2}{|c|}{$\begin{array}{l}\text { Cs/PVA (1:9) } \\
(1,000 \mathrm{ppm})\end{array}$} & \multicolumn{2}{|c|}{$\begin{array}{l}\text { Cs/PVA (4:6) } \\
(250 \mathrm{ppm})\end{array}$} & \multirow{2}{*}{ - $p$-value } \\
\hline & $\begin{array}{l}\text { Survival } \\
\text { fraction } \% \\
\end{array}$ & $\begin{array}{l}\text { Inhibition } \\
\text { ratio \% }\end{array}$ & $\begin{array}{l}\text { Survival } \\
\text { fraction } \%\end{array}$ & $\begin{array}{l}\text { Inhibition } \\
\text { ratio } \%\end{array}$ & $\begin{array}{l}\text { Survival } \\
\text { fraction } \%\end{array}$ & $\begin{array}{l}\text { Inhibition } \\
\text { ratio \% }\end{array}$ & \\
\hline 0.0 & 100 & 0 & 100 & 0 & 100 & 0 & \multirow{5}{*}{$<0.001$} \\
\hline 5.00 & 76.2 & 23.8 & 71.4 & 28.6 & 88.1 & 11.9 & \\
\hline 12.5 & 61.9 & 38.1 & 57.1 & 42.9 & 61.9 & 38.1 & \\
\hline 25.00 & 33.3 & 66.7 & 29.5 & 70.5 & 33.3 & 66.7 & \\
\hline 50.00 & 24.8 & 75.2 & 18.1 & 81.9 & 23.8 & 76.2 & \\
\hline $\mathrm{IC}_{50}(\mu \mathrm{g} / \mathrm{mL})$ & \multicolumn{2}{|c|}{17.8} & \multicolumn{2}{|r|}{15.6} & \multicolumn{2}{|c|}{17.8} & \\
\hline
\end{tabular}

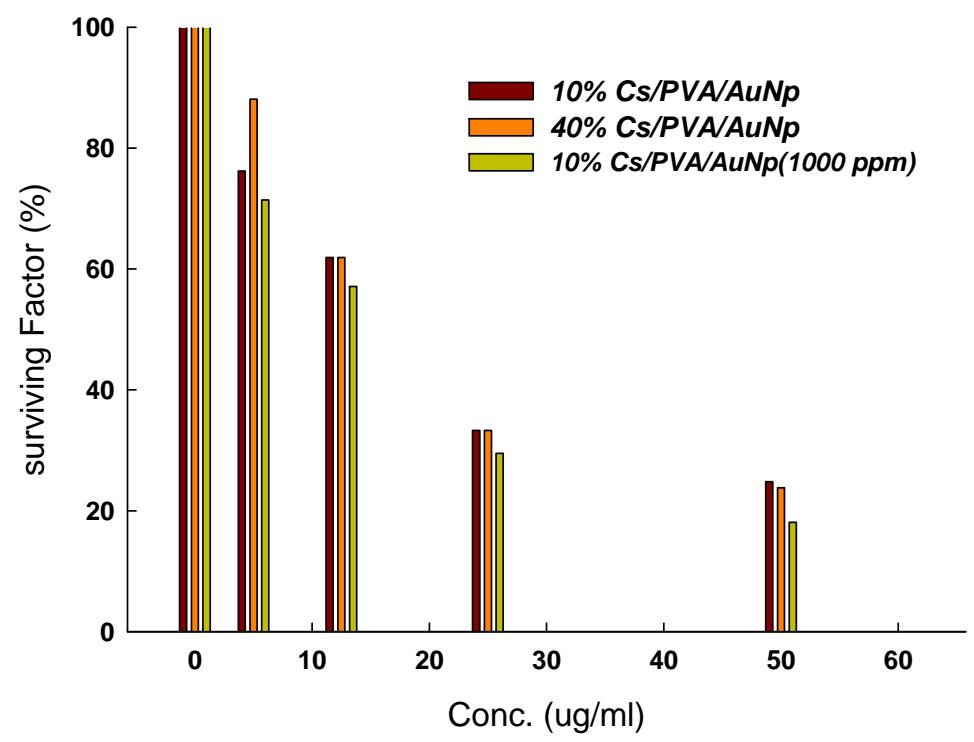

Fig. 6 Surviving factor (\%) of PC3 cells after 48-h treatment with different concentrations of Cs/PVA/AuNP, as calculated from the SRB assay. 
concentration of (4:6) and (1:9) with $250 \mathrm{ppm}$ AuNP. The $\mathrm{IC}_{50}$ was the same in both. The survival fraction was improved to $18.1 \%$ with increasing ppm AuNP to 1000. This improving was highly statistically significant ( $p$-value $\leq 0.001$ ). The $\mathrm{IC}_{50}$ was $15.6 \mu \mathrm{g} / \mathrm{mL}$. This is in accordance with Patil et al. 2017 [50], who determined the effects of AuNPs on the proliferation of MKN-28 (Adenocarcinoma), Hep3B (Hepatocellular carcinoma), and MG-63 (Osteosarcoma) cell lines and recorded the increasing cytotoxicity of AuNPs from MKN-28 to MG-63 to Hep3B. He found that the AuNP concentration of $50 \mu \mathrm{g} / \mathrm{mL}$ was not very active. However, he observed a high cytotoxic activity with increasing the concentration to $100 \mu \mathrm{g} / \mathrm{mL}$ and the 200 $\mu \mathrm{g} / \mathrm{mL}$ sample reduced all cells to around $20 \%$ viability. They also, observed $50 \%$ of cell inhibition at an AuNPs concentration of approximately $150 \mu \mathrm{g} / \mathrm{mL}$. There are limited studies on the cytotoxic effects of AuNPs against different cancer cells especially on prostatic cancer cell line. On the other hand, modern oncologic or anticancer studies aim towards designing newer compounds showing enhanced antiproliferative potential and not as much of associated toxicity than cisplatin. On this regard, Al-Jaroudi et al. 2014 [51] developed a new series of gold(III) complexes (1-3) containing mixed ethylenediamine (en) and 1, 2DACH ligands and evaluated them for antiproliferation against PC 3 cancer cell lines. As the in-vitro cytotoxic activity depends on the exposure time and the concentration of complexes, the growth inhibition was studied for 24-72 h using fixed concentration of 10 and $20 \mu \mathrm{g} / \mathrm{mL}$ concentrations. They found that, the complexes (1) and (3) showed better cell inhibition against PC3 cell line than complex (2). The cell inhibition was augmented with the increase in concentration of the complexes. However, the $\mathrm{IC}_{50}$ value for PC3 cancer cells of complexes showed that the complexe (1) is relatively more effective cytotoxic agent than complexes (2) and (3) which is comparable to cisplatin [52]. Gold complexes have recently gained significant attention as a class of compounds with different pharmacodynamic and kinetic properties than cisplatin with strong cell growth inhibiting effects [53, 54]. The cell growth inhibiting effects, in many cases, could be related to anti-mitochondrial effects that make the gold complexes interesting $[53,55,56]$. However, the NPs can be incorporated with dual targets, the androgen receptor (AR1) which is a target for prostatic cancer therapy and a G protein receptor (GRC6A), which is seen upregulated in cancer prostate. On the other hand, The NPs also could induce cell death at nanomolar concentrations of the particles and could bind to the androgen receptor with high affinity. The attachment of the gold NPs to a prostatic cancer cell lines was proved by the detection of the PC cells in a photoacoustic flowmeter, which is fabricated to identify single cell of cancer prostate in the blood sample under flow [49]. The response of gold NPs to radiations and growth suppression in human prostatic cancer cells that are radiation resistant are investigated [57]. It was found that, the glucose was bound to the gold NP surface and sparing the normal cells. This can improve the cellular uptake of gold NPs selectively into malignant cells. On the other hand, The NPs was improved to be toxic to prostatic cancer cells and, radiation sensitive. Neoadjuvant intake of gold NPs proved to stimulate prostatic cancer cells against external beam radiation therapy [58] and to promote in vivo laser photothermal ablation therapy in prostate cancer animal models [39, 59].

Silver nanoparticles (AgNPs) have many biomedical applications due to its excellent biocompatibility and antibacterial properties. AgNPs aid in gathering and transporting drugs into the cancer cells [60]. The cytotoxic effect of various concentrations of the silver nanoparticles (Cs/PVA/AgNP, 5, 12.5, 25 and 50 $\mu \mathrm{g} / \mathrm{mL}$ ) was evaluated in vitro against prostatic human carcinoma cell lines (PC3) (Table 3 and Fig. 7). The survival fraction and the inhibition ratio were determined. The cytotoxic activity was determined according to the dose values of the exposure of the complex required to reduce survival to $50 \%\left(\mathrm{IC}_{50}\right)$. The 
Table 3 Surviving fraction \% of prostate cancer cell line (PC3) with different concentrations of Cs/PVA/AgNP at concentrations range from 5 to $50 \mu \mathrm{g} / \mathrm{mL}$.

\begin{tabular}{|c|c|c|c|c|c|}
\hline \multirow{2}{*}{$\begin{array}{l}\text { Concentration } \\
(\mu \mathrm{g} / \mathrm{mL})\end{array}$} & \multicolumn{2}{|c|}{$\begin{array}{c}\text { Cs/PVA/AgNP, Cs:PVA (1:9) } \\
\text { (250 ppm) }\end{array}$} & \multicolumn{2}{|c|}{$\begin{array}{c}\text { Cs/PVA/AgNP, Cs:PVA (4:6) } \\
\text { (250 ppm) }\end{array}$} & \multirow[t]{2}{*}{$p$-value } \\
\hline & Surviving fraction $\%$ & Inhibition ratio $\%$ & Surviving fraction $\%$ & Inhibition ratio $\%$ & \\
\hline 0.0 & 100 & 0 & 100 & 0 & \multirow{5}{*}{0.018} \\
\hline 5.00 & 75.2 & 24.8 & 69.9 & 30.1 & \\
\hline 12.5 & 60.9 & 39.1 & 68.3 & 31.7 & \\
\hline 25.00 & 47.8 & 52.2 & 68.9 & 31.1 & \\
\hline 50.00 & 26.5 & 73.5 & 51.3 & 48.7 & \\
\hline $\mathrm{IC}_{50}(\mu \mathrm{g} / \mathrm{mL})$ & \multicolumn{2}{|c|}{23.1} & \multicolumn{2}{|c|}{ None } & \\
\hline
\end{tabular}

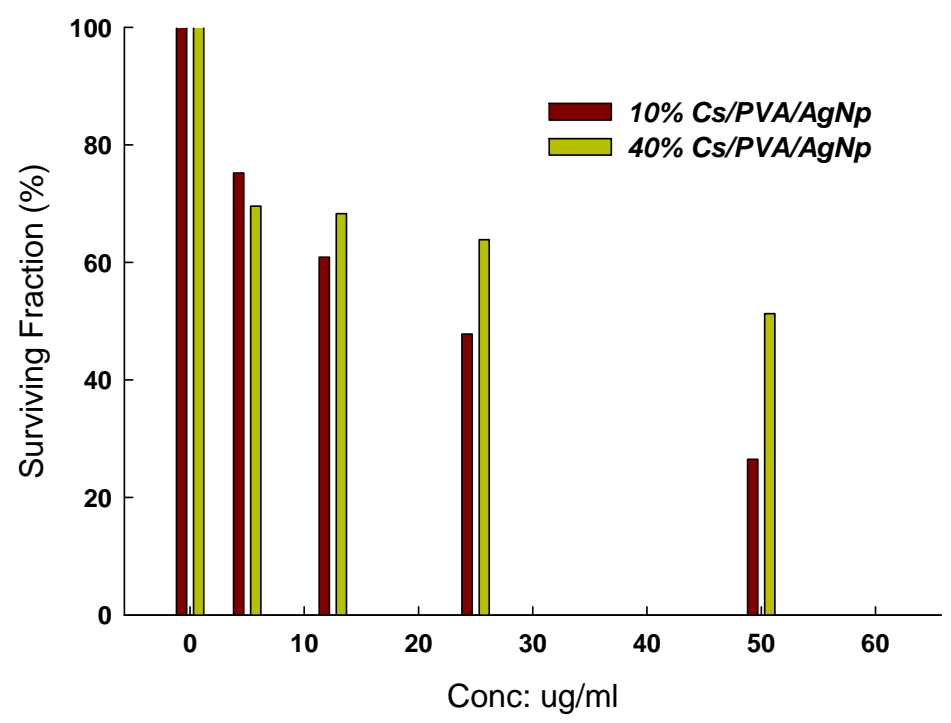

Fig. 7 Surviving factor (\%) of PC3 cells after 48-h treatment with different concentrations of Cs/PVA/AgNP, as calculated from the SRB assay.

survival fraction was found to be $26.5 \%$ and $51.3 \%$ in hydrogel concentration of (1:9) and (4:6) with $250 \mathrm{ppm}$ AgNP. The difference was statistically significant ( $p$-value $=0.018)$. The inhibition ratio in $(1: 9)$ concentration was $73.5 \%$ and the $\mathrm{IC}_{50}$ was $23.1 \mu \mathrm{g} / \mathrm{mL}$. However, there was a negative effect on the PC3 cell cultures by adding 250 ppm AgNP to (4:6) hydrogel. This result was in accordance with Osman et al. 2015 [61] who reported inhibition ratios of $78 \%$ and $61 \%$ at concentration of $50 \mu \mathrm{g} / \mathrm{mL}$ against PC3 cell line. He and his colleagues revealed a strong inhibition of $98.0 \%$ and $92.0 \%$ respectively with increasing the concentration to $100 \mu \mathrm{g} / \mathrm{mL}$ for silver nanoparticles of A. deflectus. But, they do not have any cytotoxic effect for all concentrations with silver nanoparticles of $\mathrm{P}$. pinophilum. They also found inhibition of the cell growth with $\mathrm{IC}_{50}$ values of $35 \mu \mathrm{g} / \mathrm{mL}$ and $52.4 \mu \mathrm{g} / \mathrm{mL}$ respectively of the silver nanoparticles of $\mathrm{A}$. deflectus under optimized and irradiated condition. Contrary, Mansour et al. 2018 [21], found that AgNP has no cytotoxic activity against PC3 cell line. Additionally, silver nanoparticles obstruct with metabolism of cancer and tumor proliferation [62]. It can display a synergistic effect [60] and a cytotoxic effect on cell viability which have a chief role in antitumor and anticancer activity [63]. Previous studies reported that AgNPs can induce cell death in vitro and in vivo through a reactive oxygen species (ROS)-mediated apoptotic process [61, 64]. Gopinath et al. 2008 [65], suggested that, Ag NPs by themselves may also act as a 

with Gold and Silver Nanoparticles in Treatment of Prostatic Cancer Model

therapeutic drug. It may assume significance in the development of a suitable anticancer drug and may lead to novel nanomedicines with strong potential in therapeutic use for treatment of cancers and in conjunction with conventional gene therapy.

\section{Conclusions}

Cancer diagnosis, therapy and monitoring have been greatly influenced by nanotechnology. Various approaches have been developed to specifically targeted the diagnose and treatment of cancer prostate. Metallic and metal oxide NPs such as gold, and silver, are widely studied and shown a great result in the therapy of this type of cancer. Polymeric NPs were also found to be effective carriers for the delivery of the NPs. In the current study, Cs/PVA blend was synthesized by gamma radiation which could behave a nanoreactor for $\mathrm{Ag}$ and $\mathrm{Au}$ nanoparticle with promising anticancer applications. Cs/PVA/Ag and $\mathrm{Cs} / \mathrm{PVA} / \mathrm{Au}$ nanocomposites were confirmed by SEM, and TEM analysis. The anti-cancer activity of the prepared nanocomposites was demonstrated in prostatic cancer cell line and it has a significant effect against prostatic cancer. Future and challenges nanomaterials are potential tools of tremendous benefits that are now starting to be applied in the clinic. Soon improvements can be made to develop alternative medicine, metallic and metal oxide and polymeric NPs for their targeted delivery along with the anticancer agents to the site of prostate cancer and to treat the tumor with minimal side effects and damage to the normal cells. The study concluded that, the developing nanoparticle therapy in the right directions will improve the outcome of cancer patients and impact the future nanomedicine greatly.

\section{References}

[1] Venkatesan, J., Lee, J.-Y., Kang, D. S., Anil, S., Kim, S.-K., Shim, M. S., and Kim, D. G. 2017. “Antimicrobial and Anticancer Activities of Porous Chitosanalginate Biosynthesized Silver Nanoparticles.” Int $J$ Biol Macromol. 98: 515-25. http://dx.doi.org/doi:10.1016/j.jibiomac.2017.01.120.
[2] Caló, E., and Khutoryanskiy, V. V. 2015. "Biomedical Applications of Hydrogels: A Review of Patents and Commercial Products.” Euro Polymer J. 65: 252-67.

[3] Kumar, M. N., Muzzarelli, R. A. A., Muzzarelli, C., Sashiwa, H., and Domb, A. J. 2004. "Chitosan Chemistry and Pharmaceutical Perspectives.” Chem. Rev. 104 (12): 6017-84.

[4] Venkatesan, J., Bhatnagar, I., and Kim, S. K. 2014. "Chitosan-Alginate Biocomposite Containing Fucoidan for Bone Tissue Engineering.” Mar. Drugs. 12 (1): 300-16.

[5] Venkatesan, J., Alam, M. S., Hong, E. J., Kim, S.-K., and Shim, M. S. 2016. "Preparation of Piperlongumine-Loaded Chitosan Nanoparticles for Safe and Efficient Cancer Therapy.” RSC Adv. 6: 79307-16.

[6] Joshi, P., Chakraborti, S., Ramirez-Vick, J. E., Ansari, Z. A., Shanker, V., Chakrabarti, P., and Singh, S. P. 2012. "The Anticancer Activity of Chloroquine-Gold Nanoparticles against MCF-7 Breast Cancer Cells.” Colloids Surf B. Biointerfaces 95: 195-200.

[7] Venugopal, K., Ahmad, H., Manikandan, E., Thanigai Arul, K., Kavitha, K., Moodley, M. K., Rajagopal, K., Balabhaskar, R., and Bhaskar, M. 2017. "The Impact of Anticancer Activity upon Beta Vulgaris Extract Mediated Biosynthesized Silver Nanoparticles (ag-NPs) against Human Breast (MCF-7), Lung (A549) and Pharynx (Hep-2) Cancer Cell Lines.” J Photochem Photobiol B. 173: 99-107.

[8] Sanna, V., Pala, N., Dessì, G., Manconi, P., Mariani, A., Dedola, S., Rassu, M., Crosio, C., Iaccarino, C., and Sechi, M. 2014. "Single-Step Green Synthesis and Characterization of Gold-Conjugated Polyphenol Nanoparticles with Antioxidant and Biological Activities.” Int J Nanomedicine 9: 4935-51.

[9] De Jong, W. H., and Borm, P. J. A. 2008. "Drug Delivery and Nanoparticles: Applications and Hazards.” Int. J. Nanomedicine 3 (2): 133-49.

[10] Prow, T. W., Grice, J. E., Lin, L. L., Faye, R., Butler, M., Becker, W., Wurm, E. M., Yoong, C., Robertson, T. A., Soyer, H. P., and Roberts, M. S. 2011. "Nanoparticles and Microparticles for Skin Drug Delivery.” Adv. Drug Deliv. Rev. 63 (6): 470-91.

[11] Chaloupka, K., Malam, Y., and Seifalian, A. M. 2010. "Nanosilver as a New Generation of Nanoproduct in Biomedical Applications.” Trends Biotechnol 28 (11): 580-8.

[12] Rai, M., Yadav, A., and Gade, A. 2009. "Silver Nanoparticles as a New Generation of Antimicrobials.” Biotechnol Adv. 27 (1): 76-83.

[13] Krutyakov, Y. A., Kudrinskiy, A. A., Olenin, A. Y., and Lisichkin, G. V. 2008. "Synthesis and Properties of Silver Nanoparticles Advances and Prospects.” Chem. Rev. 77 


\section{Characterization and Antitumor Activity of Chitosan/Poly (Vinyl Alcohol) Blend Doped with Gold and Silver Nanoparticles in Treatment of Prostatic Cancer Model}

(3): 233-5.

[14] Kelly, F. M., and Johnston, J. H. 2011. "Colored and Functional Silver Nanoparticle-Wool Fiber Composites.” ACS Appl. Mater. Interfaces 3 (4): 1083-92.

[15] Dankovich, T. A., and Gray, D. G. 2011. "Bactericidal Paper Impregnated with Silver Nanoparticles for Point-of-Use Water Treatment.” Environ. Sci. Technol. 45 (5): 1992-8.

[16] Chaudhry, Q., and Castle, L. 2011. "Food Applications of Nanotechnologies: An Overview of Opportunities and Challenges for Developing Countries.” Trends Food Sci. Technol. 22: 595-603.

[17] Nair, R., Varghese, S. H., Nair, B. G., Maekawa, T., Yoshida, Y., and Sakthi, K. D. 2010. "Nanoparticulate Material Delivery to Plants.” Plant Sci. 179: 154-63.

[18] Bajpai, S. K., Mohan, Y. M., Bajpai, M., Tankhiwale, R., and Thomas, V. 2007. "Synthesis of Polymer Stabilized Silver and Gold Nanostructures.” J Nanosci Nanotechnol. 7 (9): 2994-3010

[19] Vimala, K., Ksamba, S., Ymurali, M., Sreedhar, B., and Kmohana, R. 2009. "Controlled Silver Nanoparticles Synthesis in Semi-hydrogel Networks of Poly (Acrylamide) and Carbohydrates: A Rational Methodology for Antibacterial Application.” Carbohydrate Polymers 75 (3): 463-71.

[20] Aggor, F. S., Ahmed, E. M., El-Aref, A. T., and Asem, M. A. 2010. "Synthesis and Characterization of Poly (Acrylamide-Co-Acrylic Acid) Hydrogel Containing Silver Nanoparticles for Antimicrobial Applications.” $J$ Am Sci. 6 (12): 648-56.

[21] Mansour, H., Eid, M., and El-Arnaouty, M. 2018. "Effect of Silver Nanoparticles Synthesized by Gamma Radiation on the Cytotoxicity of Doxorubicin in Human Cancer Cell Lines and Experimental Animals.” Hum Exp Toxicol. 37 (1): 38-50.

[22] Vichai, V., and Kirtikara, K., and Sulforhodamine, B. 2006. "Colorimetric Assay for Cytotoxicity Screening." Nat. Protoc. 1 (3): 1112-6.

[23] Abdeen, Z., Mohammad, S., and Mahmoud, M. 2015. “Adsorption of Mn (II) Ion on Polyvinyl Alcohol/Chitosan Dry Blending from Aqueous Solution.” Environmental Nanotechnology, Monitoring \& Management 3: 1-9.

[24] Kim, S. J., Park, S. J., Kim, I. Y., Shin, M.-S., and Kim, S. I. 2002. "Electric Stimuli Responses to Poly (Vinyl Alcohol)/Chitosan Interpenetrating Polymer Network Hydrogel in NaCl Solutions.” Inc. J Appl Polym Sci. 86: 2285-9.

[25] Sung, J. H., Hwang, M. R., Kim, J. O., Lee, J. H., Kim, Y. I., Kim, J. H., Chang, S. W., Jin, S. G., Kim, J. A., Lyoo, W. S., Han, S. S., Ku, S. K., Yong, C. S., and Choi, H. G. 2010. "Gel Characterisation and in Vivo Evaluation of Minocycline-Loaded Wound Dressing with Enhanced
Wound Healing Using Polyvinyl Alcohol and Chitosan.” Int J Pharm. 392 (1-2): 232-40.

[26] Tahtat, D., Mahlous, M., Benamer, S., Nacer Khodja, A., Larbi Youcef, S., Hadjarab, N., and Mezaache, W. 2011. "Influence of Some Factors Affecting Antibacterial Activity of PVA/Chitosan Based Hydrogels Synthesized by Gamma Irradiation.” J Mater Sci Mater Med. 22 (11): 2505-12.

[27] Khalid, M. N., Agnely, F., Yagoubi, N., Grossiord, J. L., and Couarraze, G. 2002. "Water State Characterization, Swelling Behavior, Thermal and Mechanical Properties of Chitosan Based Networks.” Eur J Pharm Sci. 15 (5): 425-32.

[28] Cascone, M., Maltinti, S., Barbani, N., and Laus, M. 1999. "Effect of Chitosan and Dextran on the Properties of Poly (Vinyl Alcohol) Hydrogels.” J Mater Sci Mater Med. 10 (7): 431-5.

[29] Abou Taleb, M., Hegazy, D. E., and Mahmoud, G. A. 2014. "Characterization and In-Vitro Drug Release Behavior of (2-Hydroxyethyl Methacrylate)-co-(2-Acrylamido-2-Methyl-1-Propanesulf onic Acid) Crosslinked Hydrogels Prepared by Ionizing Radiation.” Int. J. Polym. Mater. 63: 840-5.

[30] Tang, Y.-F., Du, Y.-M., Hu, X.-W., Shi, X.-W., and Kennedy, J. F. 2007. "Rheological Characterisation of a Novel Thermosensitive Chitosan/Poly (Vinyl Alcohol) Blend Hydrogel.” Carbohyd Polym. 67 (4): 491-9.

[31] Li, X., Wu, W., and Liu, W. 2008. "Synthesis and Properties of Thermo-responsive Guar Gum/Poly ( $N$-Isopropylacrylamide) Interpenetrating Polymer Network Hydrogels.” Carbohyd Polym. 71 (3): 394-402.

[32] Vimala, K., Yallapu, M. M., Varaprasad, K., Reddy, N. N., Ravindra, S., Naidu, N. S., and Raju, K. M. 2011. "Fabrication of Curcumin Encapsulated Chitosan-PVA Silver Nanocomposite Films for Improved Antimicrobial Activity.” J Biomater Nanobiotechnol 2 (1): 55-64.

[33] Kim, J.-H., and Lee, T. R. 2004. "Thermo- and pH-Responsive Hydrogel-Coated Gold Nanoparticles.” ACS CM. 16 (19): 3647-51.

[34] Agnihotri, S., Mukherji, S., and Mukherji, S. 2012. "Antimicrobial Chitosan-PVA Hydrogel as a Nanoreactor and Immobilizing Matrix for Silver Nanoparticles.” Appl Nanosci. 2 (3): 179-88.

[35] Xu, Y., Wen, Z., and Xu, Z. 2009. "Chitosan Nanoparticles Inhibit the Growth of Human Hepatocellular Carcinoma Xenografts through an Antiangiogenic Mechanism.” Anticancer Res. 29 (12): 5103-9.

[36] Brannon-Peppas, L., and Blanchette, J. O. 2012. "Nanoparticles and Targeted Systems for Cancer Therapy." Adv. Drug Deliv. Rev. 64: 206-12.

[37] Loutfy, S. A., El-Din, H. M. A., Elberry, M. H., Allam, N. 
G., Hasanin, M., and Abdellah, A. M. 2016. "Synthesis, Characterization and Cytotoxic Evaluation of Chitosan Nanoparticles: In Vitro Liver Cancer Model.” Adv. Nat. Sci. Nanosci. Nanotechno. 7 (3): 035008. 2043-6262.

[38] Jemal, A., Bray, F., Center, M. M., Ferlay, J., Ward, E., and Forman, D. 2011. "Global Cancer Statistics." CA-Cancer. J. Clin. 61 (2): 69-90.

[39] Cherian, A. M., Nair, S. V., and Lakshmanan, V.-K. 2014. The Role of Nanotechnology in Prostate Cancer. Theranostic Applications. J. Nanosci. Nanotechnol 14 (1): 841-52.

[40] Jeon, Y. J., and Kim, S. K. 2002. “Antitumor Activity of Chitosan Oligosaccharides Produced in Ultrafiltration Membrane Reactor System.” J. Microbiol. Biotechnol. 12: 503-7.

[41] Azab, A. K., Kleinstern, J., Doviner, V., Orkin, B., Srebnik, M., Nissan, A., and Rubinstein, A. 2007. "Prevention of Tumor Recurrence and Distant Metastasis Formation in a Breast Cancer Mouse Model by Biodegradable Implant of 131I-Norcholesterol." J. Control. Release 123 (2): 116-22.

[42] Lesniak, M. S., and Brem, H. 2004. "Targeted Therapy for Brain Tumours.” Nat Rev Drug Discov. 3 (6): 499-508.

[43] Ruel-Gariepy, E., Shive, M., Bichara, A., Berrada, M., Le Garrec, D., Chenite, A., and Leroux, J. C. 2004. "A Thermosensitive Chitosan-Based Hydrogel for the Local Delivery of Paclitaxel.” Eur. J. Pharm. Biopharm. 57 (1): 53-63.

[44] Ranjha, N. M., and Khan, S. 2013. “Chitosan/Poly (Vinyl Alcohol) Based Hydrogels for Biomedical Applications: A Review.” J Pharm and Alter Med. 2 (1): 30-41. www.iiste.org. ISSN 2222-5668 (Paper) ISSN 2222-4807 (Online).

[45] Kumar, A., Huo, S., Zhang, X., Liu, J., Tan, A., Li, S., Jin, S., Xue, X., Zhao, Y., Ji, T., Han, L., Liu, H., Zhang, X., Zhang, J., Zou, G., Wang, T., Tang, S., and Liang, X. J. 2014. "Neuropilin-1-Targeted Gold Nanoparticles Enhance Therapeutic Efficacy of Platinum (IV) Drug for Prostate Cancer Treatment.” ACS Nano. 8 (5): 4205-20.

[46] Tsai, L.-C., Hsieh, H.-Y., Lu, K.-Y., Wang, S.-Y., and Mi, F.-L. 2016. "EGCG/Gelatin-Doxorubicin Gold Nanoparticles Enhance Therapeutic Efficacy of Doxorubicin for Prostate Cancer Treatment.” Nanomed. (Lond.) 11 (1): 9-30

[47] Shukla, R., Chanda, N., Zambre, A., Upendran, A., Katti, K., Kulkarni, R. R., Nune, S. K., Casteel, S. W., Smith, C. J., Vimal, J., Boote, E., Robertson, J. D., Kan, P., Engelbrecht, H., Watkinson, L. D., Carmack, T. L., Lever, J. R., Cutler, C. S., Caldwell, C., Kannan, R., and Katti, K. V. 2012. "Laminin Receptor Specific Therapeutic Gold Nanoparticles (198AuNP-EGCg) Show Efficacy in Treating Prostate Cancer.” Proc. Natl. Acad. Sci. USA.
109 (31): 12426-31.

[48] Dreaden, E. C., Gryder, B. E., Austin, L. A., Tene Defo, B. A., Hayden, S C., Pi, M., Quarles, L. D., Oyelere, A. K., and El-Sayed, M. A. 2012. “Antiandrogen Gold Nanoparticles Dual-Target and Overcome Treatment Resistance in Hormone-Insensitive Prostate Cancer Cells.” Bioconjug. Chem. 23 (8): 1507-12.

[49] Viator, J. A., Gupta, S., Goldschmidst, B. S., Bhattacharyyal, K., Kannan, R., Shukla, R., Dale, P. S., Boote, E., and Katti, K. 2010. "Gold Nanoparticle Mediated Detection of Prostate Cancer Cells Using Photoacoustic Flowmetry with Optical Reflectance.” J. Biomed. Nanotechnol 6 (2): 187-91.

[50] Patil, M. P., Ngabire, D., Thi, H. H. P., Kim, M.-D., and Kim, G.-D. 2017. "Eco-friendly Synthesis of Gold Nanoparticles and Evaluation of Their Cytotoxic Activity on Cancer Cells.” J Clust Sci. 28 (1): 119-32.

[51] Al-Jaroudi, S. S., Monim-ul-Mehboob, M., Altaf, M., Al-Saadi, A. A., Wazeer, M. I. M., Altuwaijri, S., and Isab, A. A. 2014. "Synthesis, Spectroscopic Characterization, Electrochemical Behavior and Computational Analysis of Mixed Diamine Ligand Gold (III) Complexes: Antiproliferative and in Vitro Cytotoxic Evaluations against Human Cancer Cell Lines.” Biometals 27 (6): 1115-36.

[52] Monim-ul-Mehboob, M., Altaf, M., Fettouhi, M., Isab, A. A., Wazeer, M. I. M., Shaikh, M. N., and Altuwaijri, S. 2013. "Synthesis, Spectroscopic Characterization and Anti-cancer Properties of New Gold(III)-Alkanediamine Complexes against Gastric, Prostate and Ovarian Cancer Cells; Crystal Structure of $\left[\mathrm{Au}_{2}(\mathrm{pn})_{2}(\mathrm{Cl})_{2}\right] \mathrm{Cl}_{2} \mathrm{H}_{2} \mathrm{O}$." Polyhedron 61: 225-34.

[53] Kouroulis, K. N., Hadjikakou, S. K., Kourkoumelis, N., Kubicki, M., Male, L., Hursthouse, M., Skoulika, S., Metsios, A. K., Tyurin, V. Y., Dolganov, A. V., Milaeva, E. R., and Hadjiliadis, N. 2009. "Synthesis, Structural Characterization and in Vitro Cytotoxicity of New Au(III) and $\mathrm{Au}(\mathrm{I})$ Complexes with Thioamides. Dalton Trans. 47: 10446-56.

[54] Altaf, M., Monim-ul-Mehboob, M., Seliman, A. A., Sohail, M., Wazeer, M. I. M., Isab, A. A., Li, L., Dhuna, V., Bhatia, G., and Dhuna, K. 2015. "Synthesis, Characterization and Anticancer Activity of Gold(I) Complexes that Contain Tri-tert-butylphosphine and Dialkyl Dithiocarbamate Ligands.” Euro J Med Chem. 95: 464-72

[55] Jankovic', S. M., Djekovic', A., Bugarc 'ic', Z. D., Jankovic', S. V., Lukic', G., Folic, M., and C`anovic', D. 2012. "Effects of Aurothiomalate and Gold(III) Complexes on Spontaneous Motility of Isolated Human Oviduct.” Biometals 25: 919-25.

[56] Arsenijevic', N., Volarevic', V., Milovanovic', M., and 
Bugarc`ic'Ž, D. 2013. "Gold(III) Complexes, Cytotoxic Effects." In Encyclopedia of Metalloproteins, edited by Kretsinger, R. H., Uversky, V. N., and Permyakov, E. A. Vol 2. Heidelberg: Springer, 922-7.

[57] Zhang, X., Xing, J. Z., Chen, J., Ko, L., Amanie, J., Gulavita, S., Pervez, N., Yee, D., Moore, R., and Roa, W. 2008. "Enhanced Radiation Sensitivity in Prostate Cancer by Gold-Nanoparticles." Clin Invest Med. 31 (3): E160-7.

[58] Roa, W., Zhang, X., Guo, L., Shaw, A., Hu, X., Xiong, Y., Gulavita, S., Patel, S., Sun, X., Chen, J., Moore, R., and Xing, J. Z. 2009. "Gold Nanoparticle Sensitize Radiotherapy of Prostate Cancer Cells by Regulation of the Cell Cycle." Nanotechnology 20 (37): 375101.

[59] Stern, J. M., Stanfield, J., Kabbani, W., Hsieh, J. T., and Cadeddu, J. A. 2008. "Selective Prostate Cancer Thermal Ablation with Laser Activated Gold Nanoshells." J Urol. 179 (2): 748-53.

[60] Zhou, Y., and Wang, X. 2010. "Study on Synergistic Effect of New Function Functionalized Ag Nanoparticles for Intracellular Drug Uptake in Cancer Cells." Nano Biomed Eng. 2 (4): 208-13.

[61] Osman, M. E., Eid, M. M., and Khattab, O. H. 2015. "In
Vitro Cytotoxicity of Biosynthesized Ag/CS NP against MCF7, PC3 and A549 Cancer Cell Lines." Int. J. Pharm. Tech. Res. 8: 1011-7.

[62] Probin, V., Wang, Y., Bai, A., and Zhou, D. 2006. "Busulfan Selectively Induces Cellular Senescence but Not Apoptosis in WI38 Fibroblasts via a p53-Independent but Extracellular Signal-Regulated Kinasep38 Mitogen-Activated Protein Kinase-Dependent Mechanism.” J pharmacol Exp Ther. 319 (2): 551-60.

[63] AshaRani, P. V., Low Kah Mun, G., Hande, M. P., and Valiyaveettil, S. 2009. "Cytotoxicity and Genotoxicity of Silver Nanoparticles in Human Cells." ACS Nano. 3 (2): 279-90.

[64] Thombre, R., Mehta, S., Mohite, J., and Jaisinghani, P. 2013. "Synthesis of Silver Nanoparticles and Its Cytotoxic Effect against THP-1 Cancer Cell Line.” Int J Pharm Bio Sci. 4 (1): 184-92.

[65] Gopinath, P., Gogoi, S. K., Chattopadhyay, A., and Ghosh, S. S. 2008. "Implications of Silver Nanoparticle Induced Cell Apoptosis for in Vitro Gene Therapy." Nanotechnology $19 \quad$ (7): $075104 \quad$ (10pp). doi:10.1088/0957-4484/19/7/075104. 